\title{
Low impact of disturbance on ecological success of invasive tree and shrub species in temperate forests
}

\author{
Marcin K. Dyderski $\mathbb{B} \cdot$ Andrzej M. Jagodziński $\mathbb{B}$
}

Received: 10 June 2018/ Accepted: 26 September 2018/Published online: 1 October 2018

(C) The Author(s) 2018

\begin{abstract}
Disturbance is claimed to be one of the most important triggers of biological invasions. There is a lack of data about disturbance impacts on the youngest life stage of invasive trees and shrubs. Thus, we aimed to assess the role of disturbances in shaping responses of natural regeneration of three model invasive species-Prunus serotina Ehrh., Quercus rubra L., and Robinia pseudoacacia L.- to disturbances in forest plant communities. Our study was conducted over 3 years on 372 study plots $\left(100 \mathrm{~m}^{2}\right)$, across nine types of temperate forests in Wielkopolski National Park (Poland). Disturbance was assessed using ecological indicator values for disturbance severity and frequency. Our study revealed the high importance of disturbance on species composition of understory vegetation. We also found relationships
\end{abstract}

Communicated by Lesley Rigg.

Electronic supplementary material The online version of this article (https://doi.org/10.1007/s11258-018-0885-4) contains supplementary material, which is available to authorized users.

M. K. Dyderski · A. M. Jagodziński

Institute of Dendrology, Polish Academy of Sciences,

Parkowa 5, 62-035 Kórnik, Poland

M. K. Dyderski $(\bowtie) \cdot$ A. M. Jagodziński

Faculty of Forestry, Department of Forest Protection,

Poznań University of Life Sciences, Wojska Polskiego 28,

60-637 Poznań, Poland

e-mail: Marcin.Dyderski@gmail.com between ecological success (density and biomass of natural regeneration) of invaders and disturbance indices. These models were statistically significant but their effect sizes were low. Due to the low effect sizes, we can state only limited conclusions about impact of disturbance on ecological success of invasive species natural regeneration. The results suggest that for seedlings (up to $50 \mathrm{~cm}$ height - threshold between understory and shrub layer) disturbance, a leading factor in biological invasions of numerous taxa, has a small role in this case. Thus, we may assume that their ecological success is connected with stochastic processes in populations of the invader's seedlings, rather than with stochastic release from competition caused by disturbances.

Keywords Black cherry $\cdot$ Northern red oak $\cdot$ Black locust · Intermediate-disturbance hypothesis . Saplings

\section{Introduction}

Biological invasions are one of the major threats to biodiversity (Mack et al. 2000; Davis 2003; Essl et al. 2017). Ecological success of invasive species is a derivate of three groups of factors: species invasiveness, habitat invasibility, and propagule pressure. Species invasiveness compromises life history traits 
providing advantages over native species, which allow alien species to establish in their secondary range (e.g., Tecco et al. 2010; Pyšek et al. 2014; Gallien et al. 2016). Habitat invasibility describes its vulnerability to colonization by alien species (e.g., Lonsdale 1999; Alpert et al. 2000; Richardson and Pyšek 2006). Propagule pressure reflects quantity, quality, and availability of alien species' dispersal units (e.g., Lockwood et al. 2005; Krrivánek et al. 2006; Vanhellemont et al. 2009). However, invasion success depends not merely on these factors treated separately, but rather on their interactions (e.g., Alpert et al. 2000; Davis et al. 2005; Jagodziński et al. 2015).

Disturbance is a catastrophic event removing part of the ecosystem biomass, caused by biotic or abiotic factors. Examples include biotic insect outbreaks (Jonášová and Prach 2004; Kučerová et al. 2008; Zeppenfeld et al. 2015) and abiotic wildfires (Clarke et al. 2015; Benscoter et al. 2015; Frelich et al. 2017). Human activity may also create disturbance events (e.g., Prach et al. 2001, 2014; Dyderski et al. 2016). Disturbance regimes differ in both frequency and severity, i.e., length of interval between consecutive disturbance events and in proportion of biomass destroyed during single disturbance events (Herben et al. 2016, 2018). Thus, some plant species are adapted to disturbed habitats, which is manifested in their life strategies (Grime 2001; Pierce et al. 2013; Herben et al. 2018), reflecting their functional traits (Baker 1974; Westoby 1998; Prach et al. 2001). For that reason, disturbance is one of the major factors shaping species composition of vegetation in some biomes (Turetsky and Louis 2006; Johnstone et al. 2016; Frelich et al. 2017).

Disturbance dependency is an example of invasion ecology concepts merging these aspects (Hobbs and Huenneke 1992; Chabrerie et al. 2008; Jeschke 2014; Rodríguez et al. 2017). This concept assumes that invasive species reach higher ecological success in disturbed sites (habitat parameter). As intermediate disturbances lead to increase of species richness (Fox 1979), according to the biotic acceptance theory (Stohlgren et al. 2006), this leads to the increase of alien species richness. Moreover, changes in disturbance frequency and intensity (both increase and decrease), as well as change of disturbance type may alter the species composition and create the opportunities for invasive species (Hobbs and Huenneke 1992). For that reason, species with functional traits favoring disturbance have higher spread availability in the secondary range (invasiveness). Moreover, disturbed sites may attract species that are vectors of propagules, e.g., frugivorous birds, increasing propagule availability (propagule pressure). Disturbance is also claimed to be a reason for invasions in agroecosystems (Baker 1974; Groves 2006), riparian landscapes (Pyšek and Prach 1993; Richardson et al. 2007; Dyderski and Jagodziński 2016), or urban ecosystems (Knapp et al. 2010; Jarošík et al. 2011; Obidziński et al. 2016), as well as in natural forests (Chmura and Sierka 2007). Nevertheless, our literature review did not find studies about disturbance impacts on the youngest life stage of invasive trees and shrubs.

The aim of this study was to assess the role of disturbances in shaping forest understory vegetation and responses of invasive tree and shrub species to disturbances in forest plant communities. Based on earlier studies on invasion ecology we hypothesized that (1) disturbances are more important factor shaping species composition of vegetation than fertility gradient, (2) invasive species perform better (i.e., reaching higher biomass and density of natural regeneration) in plant communities with more frequent and more severe disturbances, and (3) invasive species will respond differently to disturbance indices-competitive species responses will be negative and ruderal species responses positive.

\section{Materials and methods}

\section{Species studied}

As model species, we used the three most frequent woody alien species invading forest ecosystems in Europe (Wagner et al. 2017): Prunus serotina Ehrh., Quercus rubra L., and Robinia pseudoacacia L. All these species come from the eastern part of North America and were introduced for forest management purposes (Starfinger et al. 2003; Cierjacks et al. 2013; Woziwoda et al. 2014). P. serotina in its native range is a tree but in Europe it is most frequently a tall shrub. Due to high rate of leaf litter decomposition, $P$. serotina was widely used as a soil improver (Muys et al. 1992; Aerts et al. 2017; Horodecki and Jagodziński 2017). P. serotina is able to wait out unfavorable environmental conditions (insufficient light availability) by slow growth rates of seedlings 
(Closset-Kopp et al. 2007) and benefit from opportunity windows in resource availability (Chabrerie et al. 2008). This species is mainly dispersed by birds (Pairon et al. 2006). Q. rubra, due to large seed mass, is a species strongly dependent on propagule pressure (Riepšas and Straigyté 2008; Myczko et al. 2014; Jagodziński et al. 2018), but also able to use carbohydrate reserves stored in the acorn (Ziegenhagen and Kausch 1995). R. pseudoacacia is a wind-dispersed, pioneer tree species, that usually colonizes disturbed areas (Cierjacks et al. 2013; Vítková et al. 2017; Sádlo et al. 2017), especially due to its ability to fix nitrogen (Boring and Swank 1984; Rice et al. 2004). Thus, the species studied have differing responses to disturbance. In Poland, P. serotina prefers less-fertile sites and $R$. pseudoacacia-those more fertile, while $Q$. rubra-both less-fertile and more fertile sites (Chmura 2004; Halarewicz 2012; Gazda and Szwagrzyk 2016).

\section{Study area}

The study was conducted in the forests of Western Poland, within Wielkopolski National Park $\left(52^{\circ} 16^{\prime} \mathrm{N}\right.$, $\left.16^{\circ} 48^{\prime} \mathrm{E}\right)$. This national park covers an area of 7584 ha and its aim is to preserve a valuable post-glacial landscape, including valleys, moraine hills, and lakes. Climate of the study area is temperate, transitional between oceanic and continental. In the years 1951-2010, mean annual temperature was $8.4{ }^{\circ} \mathrm{C}$ and mean annual precipitation was $521 \mathrm{~mm}$ (Poznań meteorological station, c.a. $15 \mathrm{~km}$ from the study area). Main soil types are luvisols (47\%) and brunic and haplic soils (30\%), podzols constitute 7\% (Nowak et al. 2000). Forests cover $61 \%$ of Wielkopolski National Park, and the most frequent plant associations are Galio sylvatici-Carpinetum, Calamagrostio arundinaceae-Quercetum, and Querco roboris-Pinetum. However, some patches are covered by fertile riparian forests (Fraxino-Alnetum, Querco-Ulmetum minoris) or poor coniferous forests (Leucobryo-Pinetum). Nevertheless, large areas of deciduous forests were planted with Pinus sylvestris before the national park was established in 1957 (Nowak et al. 2000). This replacement caused transformation of both vegetation and soil chemistry by nutrient leaching and acidification (Binkley and Giardina 1998; Zerbe and Wirth 2006). Another negative aspect of human impacts was introductions of alien woody species (Purcel 2009;
Gazda and Szwagrzyk 2016). This resulted in the presence of pure stands of alien species surrounded by large areas of forest ecosystems with different levels of disturbances and human impacts. Therefore, Wielkopolski National Park seems to be an excellent place to test hypotheses about impacts of disturbances on ecological success of invasive species.

\section{Study design}

In the study area, we established 21 block sites (nine for $Q$. rubra, six for $P$. serotina, and six for $R$. pseudoacacia), each with a central monoculture stand of invasive species housing a total of 378 plots (squares $100 \mathrm{~m}^{2}$ in area). For study design details, see Dyderski and Jagodziński (2018). In the case of $P$. serotina, occurring only as an admixture in tree stands, these are tree stands with high densities of fruiting trees. In the central part of each monoculture, we established a pair of study plots. Along each of the four sides (N, S, E, and $\mathrm{W}$ ) of the central pair, we established two pairs of plots: one nearly outside the stand - at the invasion edge, and the second pair $30 \mathrm{~m}$ from the invasion edge. The invasion edge was defined as the border between crowns of the invasive species monoculture and the surrounding trees. Thus, each study block compromised 18 study plots. The study design did not generate pseudoreplications, which may be expected due to short distances between plots in blocks, because of the high spatial heterogeneity. This was manifested in high variability of natural regeneration within plots, light availability, and microsite occurrences. Because plots were distributed systematically, six of them were located within forest vegetation paths and were therefore excluded from analyses, so that the final number of plots was $n=372$. The plots were divided into nine categories according to dominant tree species: Acer platanoides-Tilia cordata-Carpinus betulus, Fagus sylvatica, Pinus sylvestris-Acer pseudoplatanus, Pinus sylvestris-Acer platanoides-Tilia cordata-Carpinus betulus, Pinus sylvestris-Prunus serotina, Pinus sylvestris-Quercus petraea, Quercus petraea, Quercus rubra, and Robinia pseudoacacia (Online Resource 1). The variability of light availability, different tree stand types, and microsite presence, allowed us to assume that the experimental design did not produce spatial clusters connected with block arrangement, which would have needed to be accounted for in the statistical design, 
e.g., by application of mixed models (Roberts et al. 2017).

During July of 2015-2017, we measured root collar diameters and heights of all trees of the study species on each plot shorter than $0.5 \mathrm{~m}$ (in total 39664 plants). Using allometric equations developed on sample trees (356 of P. serotina, 133 of Q. rubra and 158 of $R$. pseudoacacia) harvested in a 5-m buffer zone around the study plots (Online Resource 2; Dyderski and Jagodziński 2018), we estimated their total above- and belowground biomass. In addition to natural regeneration of the study species, we assessed species composition of understory vegetation, recording species identities and abundances using the BraunBlanquet method. We also measured canopy openness index (diffuse non-interceptance; DIFN) using an LAI-2200 plant canopy analyzer (Li-Cor Inc., Lincoln, NE, USA). For each plot, we recorded four series of ten samples. The measurements were conducted in August 2016, as our previous studies indicated that this month has maximal canopy foliage development (Knight et al. 2008). In March 2017, we collected four samples of leaf litter from circular plots $\left(0.16 \mathrm{~m}^{2}\right)$. The samples were dried in the oven at $65^{\circ} \mathrm{C}$ to constant mass and weighed using a balance with an accuracy of $1 \mathrm{~g}$. Litter $\mathrm{pH}$ was assessed using an electronic $\mathrm{pH}$-meter in distilled water solution after $24 \mathrm{~h}$. We used these variables as approximations of nutrient cycling rates and soil acidity in forest ecosystems.

\section{Data analysis}

Using data about vegetation species composition for each study plot, we calculated community-weighted means (CWM) of disturbance indices proposed by Herben et al. (2016). These indices reflect disturbance severity, expressed as fraction of community biomass being destroyed, and disturbance frequency, expressed as logarithm of mean time between disturbance events. These indices were developed based on expert assessment of vegetation typological units (phytosociological classes) and calibrated using a dataset of vegetation samples. The indices are correlated with functional traits reflecting disturbance responsesheight, seed mass, and clonality (Herben et al. 2016). Because disturbances in forest ecosystems may affect only the understory or the whole community, we decided to analyze both types of disturbance measures.
To assess the factors shaping vegetation species composition, we performed Detrended Correspondence Analysis (DCA) using the vegan::decorana() function (Oksanen et al. 2016). This type of multivariate analysis was chosen due to long environmental gradients ( $>3$ SD units). As an unconstrained analysis, DCA reveals dispersion of points in ordination space, reflecting particular species abundances within study plots. To determine factors correlated with the gradients revealed, we used the vegan::envfit() function (Oksanen et al. 2016) for passive projection of environmental factors: DIFN, litter mass, disturbance indices, and CWMs of specific leaf area (SLA), canopy height, and seed mass-functional traits describing plant life strategies, according to LHS concept (leaf-height-seed; Westoby 1998). LHS traits were obtained from the LEDA database (Kleyer et al. 2008). We also used proportion of species representing phytosociological classes (Ratyńska et al. 2010) and life strategies (Klotz et al. 2002). CWM computation was done using the FD::functcomp() function (Laliberté et al. 2014).

We used ordinary least squares regression to check the strength of relationships between the measures of invasive species ecological success (density and biomass of natural regeneration) and disturbance indices. Prior to analyses, we log-transformed densities and biomasses, due to log-normal distributions. Because high numbers of observations increase statistical significance of low differences between treatments as expressed by $p$ values, for our case of $n=1116$ (372 plots $\times 3$ years), we resigned from interpretation of $p$ values, which could be biased by reporting statistically significant results with little or no biological meaning (the so-called ' $p$ value hacking'), according to the American Statistical Association (Wasserstein and Lazar 2016). Instead, we focused on correlation coefficients and effect sizes. To evaluate the latter, we compared $95 \%$ confidence intervals (CI) of predicted measures of invasive species ecological success. This was done by inputting the $0.025,0.5$, and 0.975 quantiles of disturbance indices into the regression equation and visualizing the range of the values obtained. The wider the CI of predicted values, the higher the effect of the considered factor on the dependent variable. Although only $R$. pseudoacacia has assigned disturbance indices values, in regressions, we used disturbance indices calculated excluding the study species, to avoid 
circular reasoning (Thomsen et al. 2016). All analyses were conducted using $\mathrm{R}$ software ( $\mathrm{R}$ Core Team 2017).

\section{Results}

Impact of disturbance on understory vegetation

DCA (Fig. 1, Table 1) revealed two main gradients in differentiation of vegetation species composition. The first gradient (across DCA1 axis) was identified as availability of light and soil nutrients: from poor $P$. sylvestris sites with high light availability at the left to fertile oak-hornbeam and R. pseudoacacia forests at the right. This gradient also reflected functional traits connected with competition-life strategy 'c' (competitors) and high SLA CWM. The differentiation along DCA1 axis was reflected both at the tree stand and understory species composition levels, which was reflected by opposite proportions of Vaccinio-Piceetea and Querco-Fagetea species cover. The second distinct gradient (along DCA2 axis) described disturbance intensity. Low values of DCA2 indicated the presence of stress-tolerant species and ancient forest indicator species, whereas high values-presence of ' $r$ ' strategy species-were an indicator of frequent and severe disturbances. This was also correlated with proportion of meadow species (Molinio-Arrhenatheretea). The range of whole community disturbance frequency index ranged from -1.986 to -1.107 , with an average of $-1.761 \pm 0.004$, which indicated a mean turnover interval of c.a. 58 years. The analogous index for the herb layer ranged from -1.252 to -0.526 , with an average of $-0.781 \pm 0.002$, which indicated a mean turnover interval of c.a. 16 years. Whole community disturbance severity index ranged from 0.224 to 0.447 , with an average of $0.296 \pm 0.001$ and herb layer severity index ranged from 0.042 to 0.381 , with an average of $0.172 \pm 0.002$.

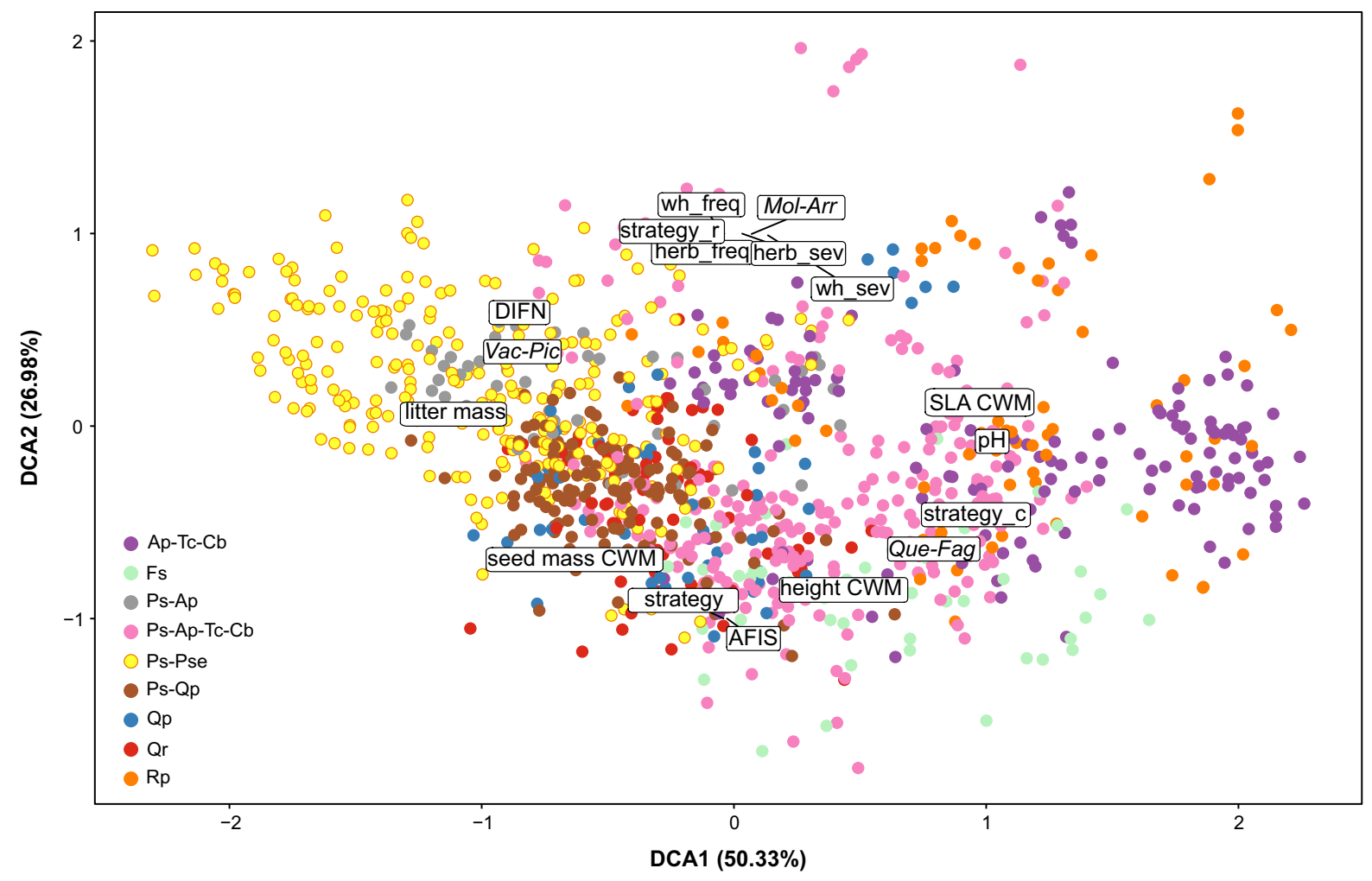

Fig. 1 DCA results conducted on understory vegetation of sample plots in three growing seasons $(n=1116)$. Labels represent passively projected environmental variables (Table 1), colors represent tree stand types: Ap-Tc-Cb, Acer platanoides-Tilia cordata-Carpinus betulus; Fs, Fagus sylvatica; Ps-Ap, Pinus sylvestris-Acer pseudoplatanus; PsAp-Tc-Cb, Pinus sylvestris-Acer platanoides-Tilia cordataCarpinus betulus; Ps-Pse, Pinus sylvestris-Prunus serotina; Ps-Qp, Pinus sylvestris-Quercus petraea; Qp, Quercus petraea, Qr, Quercus rubra; Rp, Robinia pseudoacacia (Table S1) 
Table 1 Parameters of environmental variables fitted to the DCA analysis results

\begin{tabular}{|c|c|c|c|c|c|}
\hline Parameter & Abbreviation & DCA1 & DCA2 & $R^{2}$ & $p$ \\
\hline Light availability (diffuse non-interceptance) & DIFN & -0.7295 & 0.6840 & 0.431 & 0.001 \\
\hline Litter mass & Litter mass & -0.9877 & 0.1561 & 0.478 & 0.001 \\
\hline Litter $\mathrm{pH}$ & $\mathrm{pH}$ & 0.9999 & 0.0156 & 0.593 & 0.001 \\
\hline Cover of species from class Molinio-Arrhenatheretea & Mol-Arr & 0.0699 & 0.9976 & 0.281 & 0.001 \\
\hline Querco-Fagetea & Que-Fag & 0.8269 & -0.5623 & 0.572 & 0.001 \\
\hline Vaccinio-Piceetea & Vac-Pic & -0.9567 & 0.2910 & 0.553 & 0.001 \\
\hline Cover of ancient forest indicator species & AFIS & -0.0276 & -0.9996 & 0.134 & 0.001 \\
\hline Whole community disturbance frequency index & Wh_freq & -0.0378 & 0.9993 & 0.518 & 0.001 \\
\hline Whole community disturbance severity index & Wh_sev & 0.1345 & 0.9909 & 0.226 & 0.001 \\
\hline Herb layer disturbance frequency index & Herb_freq & -0.0487 & 0.9988 & 0.167 & 0.001 \\
\hline Herb layer disturbance severity index & Herb_sev & 0.0327 & 0.9995 & 0.361 & 0.001 \\
\hline CWM of canopy height & Height CWM & 0.3097 & -0.9508 & 0.152 & 0.001 \\
\hline CWM of specific leaf area & SLA CWM & 0.9998 & 0.0208 & 0.209 & 0.001 \\
\hline CWM of seed mass & Seed mass CWM & -0.6126 & -0.7904 & 0.131 & 0.001 \\
\hline Proportion of 'c' strategy species (competitors) & Strategy_c & 0.8313 & -0.5559 & 0.066 & 0.001 \\
\hline Proportion of 'r' strategy species (ruderals) & Strategy_r & -0.1115 & 0.9938 & 0.023 & 0.002 \\
\hline Proportion of 's' strategy species (stress-tolerant) & Strategy_s & -0.0415 & -0.9991 & 0.071 & 0.001 \\
\hline
\end{tabular}

Determination coefficient $R^{2}$ and $p$ value were obtained based on permutation test with 999 iterations

CWM community-weighted mean

Impact of disturbance on invasive species ecological success

Analysis of correlations between disturbance indices and measures of success of invasive species natural regeneration (density and biomass) revealed low values of correlation coefficients. However, strength of correlations and size effects varied among species, disturbance indices, and life stages (Fig. 2, Table 2, Online Resource 3). The highest correlation coefficients were found for $P$. serotina seedling density and total $P$. serotina density and biomass, and effect of herb layer disturbance frequency index on $R$. pseudoacacia density and biomass (both seedlings and total). P. serotina density and biomass had the highest correlation coefficients in relationships with whole community frequency index and herb layer severity index, and the lowest-with herb layer frequency index. $R$. pseudoacacia biomass and density were most closely correlated with herb layer frequency index. Q. rubra did not show any relationships with the disturbance indices studied. Regarding direction of correlation (positive or negative), we found that most of the correlations with $r>0.2$ were positive. An exception was response of $R$. pseudoacacia density to herb layer frequency index. However, response of $R$. pseudoacacia biomass to the same index was positive. The best fit predictor for P. serotina total densitywhole community frequency index-predicted CI of 9.6-670.2 ind. ha ${ }^{-1}$, with median of 33.5 ind. ha ${ }^{-1}$, whereas real CI was $0.0-19812.5$ ind. $^{-1}$ and a median of 100 ind. ha ${ }^{-1}$. The best predictor for $R$. pseudoacacia seedling density-herb layer frequency index-predicted CI of $0.9-26.3$ ind. $\mathrm{ha}^{-1}$, with median of $6.2 \mathrm{ind}^{-\mathrm{ha}^{-1}}$, whereas real CI was $0.0-13550.0$ ind. ha ${ }^{-1}$, with median of 0 ind. $\mathrm{ha}^{-1}$.

\section{Discussion}

Impact of disturbance on vegetation species composition

Our study revealed that disturbance was the second factor characterizing vegetation species composition. Due to the extent of the fertility gradient, determining dominant tree species, this group of factors shaped the first gradient. Different tree species have different soil 


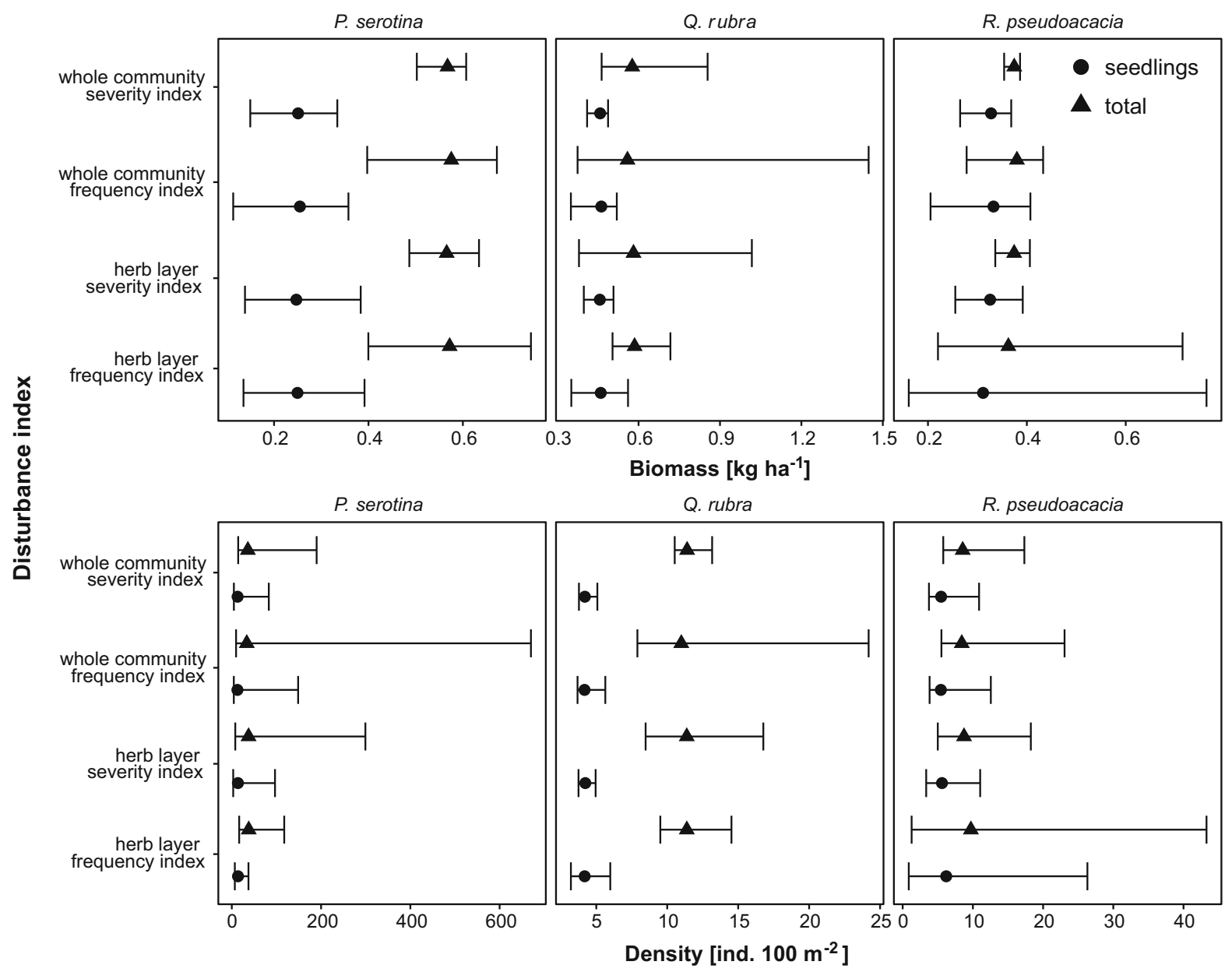

Fig. 2 Effect sizes for invasive species biomass and density prediction based on disturbance indices, modeled using simple regression (Online Resource 3). Points represent biomass or density predicted for median value of each disturbance indices,

requirements (Ellenberg 1988; Kozlowski and Pallardy 1997), but their presence also shapes soil properties by altering biogeochemical cycles (e.g., Reich et al. 2005; Hobbie et al. 2006; Mueller et al. 2012). For that reason, the fertility gradient was superior over the disturbance gradient. Our previous study conducted in the same set of study plots (Dyderski and Jagodziński 2018) revealed that soil fertility proxies influenced biomass of natural regeneration of the species studied. Patterns of invasive species abundance along fertility gradient would be related to the biotic acceptance theory, which states that plant communities richer in native species are richer in alien species (Stohlgren et al. 2006). This pattern was also confirmed in relationship between whiskers-range of $95 \%$ CI (i.e., values of 0.025 and 0.975 quantiles). Length of CI reflects relative size effect of each disturbance index within a panel

native species richness and invasive species abundance (Knight et al. 2008). Species richness is related with soil fertility (Tilman 1986), which also may limit some alien species (e.g., Pyšek and Prach 1993; Chmura 2004; Halarewicz 2012). However, the importance of soil fertility proxies in our previous study (Dyderski and Jagodziński 2018) was lower than importance of propagule pressure.

The disturbance gradient was connected with the presence of ruderals and species typical to meadows and pastures (Molinio-Arrhenatheretea) and negatively correlated with cover of ancient forest species indicators. The latter is a group of forest specialists, connected with undisturbed, long-lasting forests (Peterken 1974; Hermy et al. 1999; Dyderski et al. 
Table 2 Pearson's correlation coefficients $(r)$ between quantity of invasive species studied (rows, biomasses, and densities of seedlings) and all plants in regeneration layers up to $0.5 \mathrm{~m}$ height (total) and disturbance indices (columns; Herben et al. 2016). For regression parameters see Online Resource 3

\begin{tabular}{|c|c|c|c|c|}
\hline \multirow[t]{2}{*}{ Dependent variable } & \multicolumn{2}{|c|}{ Whole community index } & \multicolumn{2}{|c|}{ Herb layer index } \\
\hline & frequency & severity & frequency & severity \\
\hline \multicolumn{5}{|l|}{ Biomass } \\
\hline$P$. serotina seedlings & 0.083 & 0.107 & -0.017 & 0.110 \\
\hline$P$. serotina total & 0.361 & 0.186 & 0.105 & 0.300 \\
\hline Q. rubra seedlings & -0.109 & -0.040 & -0.068 & -0.075 \\
\hline Q. rubra total & 0.361 & 0.186 & 0.105 & 0.300 \\
\hline R. pseudoacacia seedlings & 0.031 & 0.121 & -0.204 & 0.117 \\
\hline R. pseudoacacia total & 0.048 & 0.103 & -0.066 & 0.097 \\
\hline \multicolumn{5}{|l|}{ Density } \\
\hline$P$. serotina seedlings & 0.249 & 0.226 & 0.065 & 0.265 \\
\hline$P$. serotina total & 0.329 & 0.222 & 0.128 & 0.297 \\
\hline Q. rubra seedlings & 0.013 & 0.028 & 0.027 & 0.015 \\
\hline Q. rubra total & 0.048 & 0.011 & 0.004 & 0.036 \\
\hline R. pseudoacacia seedlings & 0.079 & 0.089 & -0.238 & 0.096 \\
\hline R. pseudoacacia total & 0.099 & 0.102 & -0.235 & 0.111 \\
\hline
\end{tabular}

2017). These correlations provide convincing evidence that disturbance indicators elaborated by Herben et al. (2016) allow for good assessment of vegetation response to disturbances.

Impact of disturbance on studied species responses

Our study revealed that although disturbances (represented here by indices) are important factors shaping understory vegetation species composition, they have low importance in shaping ecological success of the invasive species studied. This result may seem to contradict previous studies (e.g., Chmura and Sierka 2007; Chabrerie et al. 2008; Rodríguez et al. 2017). However, the difference is connected with the life stage that we studied-natural regeneration. Seedlings of the invasive woody species reflect only one of the stages of the invasion process (Sebert-Cuvillier et al. 2007). Although this stage is crucial for further growth of invaders and their reproduction, our results show that seedling performance is shaped to only a low degree by disturbance. For that reason, our results do not contradict the previous findings, but show the exception to the general rule. Nevertheless, another study we conducted revealed that the most important predictors of biomasses of the species studied were factors describing propagule pressure (Dyderski and Jagodziński 2018). Invasion success is usually controlled by interaction of propagule pressure and invasibility (Davis et al. 2005). Thus, disturbance regime, as only one aspect of invasibility, cannot be the crucial predictor for ecological success of the species studied.

One of the possible reasons influencing the low impact of disturbance could be the relatively short gradient of disturbances within our dataset. We assumed this to be a limitation of our approach. However, Hobbs and Huenneke (1992) claim that any change of disturbance regime may create opportunity for invasive species. Herben et al. (2016) elaborated their indices for the whole range of vegetation types, from pleuston communities to the most stable forests. The highest disturbance turnover, typical to pleuston vegetation or crops, cannot possibly occur in forest ecosystems, given the high proportion of biomass destroyed annually. Values of the disturbance frequency indicators for the whole community were higher than proposed for forest plant communities (Herben et al. 2016), whereas values of herb layer disturbance frequency indicators were lower. According to the bimodal distribution of indicator values presented by Herben et al. (2016), the range of values obtained by us cover the range of the first distribution peak around -2 . Similarly, values of severity index from our study covered the peak between 0.1 and 0.4 . For that reason, we can assume that our study covered the sustainable proportion of disturbance gradients that occur in forest plant communities. This is also 
supported by the important role in shaping the species composition of vegetation shown by DCA (Fig. 1).

Different responses of disturbance of particular species studied

Despite the low importance and effect sizes of the patterns studied, we expected differences in responses of the invasive species studied to disturbance indices, connected with species biology. However, these conclusions are limited, due to low effect sizes of the relationships studied. The species most expected to be prone to disturbance, $Q$. rubra did not exhibit any relationship to the parameters studied, likely as a result of seedling dependence on carbohydrates stored in acorns (Sork 1984; Ziegenhagen and Kausch 1995). However, this effect should be lower for the case of the total regeneration layer. One possible explanation may be the ability of persistence in unsuitable conditions for one or two growing seasons, similar to the Oskar strategy of $P$. serotina (Closset-Kopp et al. 2007). Nevertheless, $P$. serotina showed positive responses to disturbances, supporting results of earlier studies (Closset-Kopp et al. 2007; Chabrerie et al. 2008; Jagodziński et al. in prep.).

For $R$. pseudoacacia, the highest correlation coefficient was found in a negative relationship between its ecological success and understory disturbance frequency index. This species is known for acting as ruderal-occupation of disturbed areas, wind dispersal, and production of large number of seeds (Cierjacks et al. 2013; Vítková et al. 2017). For that reason, we assume that this pattern may be an effect of presence of numerous $R$. pseudoacacia in plots with low light availability, thus favoring forest specialists (Dzwonko 1993; Hermy et al. 1999). In contrast, plots with abundant open habitat species did not host abundant natural regeneration of $R$. pseudoacacia.

Our study revealed that although disturbance indices are important factors shaping understory vegetation species composition, it has low importance in shaping ecological success of the invasive species studied. Due to the low effect sizes, we can state only limited conclusions about impacts of disturbance on ecological success of natural regeneration of the invasive species studied. The results suggest that for seedlings (up to $50 \mathrm{~cm}$ height) disturbance, a leading factor in biological invasions for numerous taxa, has a small role in this case. Our previous study (Dyderski and Jagodziński 2018) revealed the crucial role of propagule pressure in shaping ecological success of natural regeneration for these species. Thus, we may assume that their ecological success is more connected with stochastic processes in the invader's seedling populations than with stochastic release from competition caused by disturbances. This possibility would lead to two management implications. Firstly, risk assessments should account not for disturbed sites, but rather for propagule sources. Secondly, the regeneration layer needs monitoring as random processes, not predictable using data about disturbances, may lead to quick release of invaders (Hobbs and Huenneke 1992).

Acknowledgements The study was financed by National Science Centre, Poland, under the project no. 2015/19/N/NZ8/ 03822 entitled: 'Ecophysiological and ecological determinants of invasiveness of trees and shrubs with the examples of Padus serotina, Quercus rubra, and Robinia pseudoacacia'. We are grateful to Dr. Lee E. Frelich (Department of Forest Resources, University of Minnesota, USA) for linguistic revision of the manuscript. We also thank to the two anonymous reviewers for helpful remarks to the first draft of the manuscript.

Open Access This article is distributed under the terms of the Creative Commons Attribution 4.0 International License (http:// creativecommons.org/licenses/by/4.0/), which permits unrestricted use, distribution, and reproduction in any medium, provided you give appropriate credit to the original author(s) and the source, provide a link to the Creative Commons license, and indicate if changes were made.

\section{References}

Aerts R, Ewald M, Nicolas M et al (2017) Invasion by the alien tree Prunus serotina alters ecosystem functions in a temperate deciduous forest. Front Plant Sci 8:179. https://doi. org/10.3389/fpls.2017.00179

Alpert P, Bone E, Holzapfel C (2000) Invasiveness, invasibility and the role of environmental stress in the spread of nonnative plants. Perspect Plant Ecol Evol Syst 3:52-66. https://doi.org/10.1078/1433-8319-00004

Baker HG (1974) The evolution of weeds. Annu Rev Ecol Syst 5:1-24. https://doi.org/10.1146/annurev.es.05.110174. 000245

Benscoter BW, Greenacre D, Turetsky MR (2015) Wildfire as a key determinant of peatland microtopography. Can J For Res 45:1132-1136. https://doi.org/10.1139/cjfr-2015-0028

Binkley D, Giardina C (1998) Why do tree species affect soils? The warp and woof of tree-soil interactions. Biogeochemistry 42:89-106. https://doi.org/10.1023/A: 1005948126251 
Boring LR, Swank WT (1984) Symbiotic nitrogen fixation in regenerating black locust (Robinia pseudoacacia L.) stands [North Carolina]. For Sci 30:528-537

Chabrerie O, Verheyen K, Saguez R, Decocq G (2008) Disentangling relationships between habitat conditions, disturbance history, plant diversity, and American black cherry (Prunus serotina Ehrh.) invasion in a European temperate forest. Divers Distrib 14:204-212. https://doi.org/10.1111/ j.1472-4642.2007.00453.x

Chmura D (2004) Penetration and naturalisation of invasive alien plant species (neophytes) in woodlands of the Silesian Upland (southern Poland). Nat Conserv 60:3-11

Chmura D, Sierka E (2007) The invasibility of deciduous forest communities after disturbance: a case study of Carex brizoides and Impatiens parviflora invasion. For Ecol Manag 242:487-495. https://doi.org/10.1016/j.foreco.2007.01. 083

Cierjacks A, Kowarik I, Joshi J et al (2013) Biological Flora of the British Isles: Robinia pseudoacacia. J Ecol 101:1623-1640. https://doi.org/10.1111/1365-2745.12162

Clarke PJ, Keith DA, Vincent BE, Letten AD (2015) Postgrazing and post-fire vegetation dynamics: long-term changes in mountain bogs reveal community resilience. J Veg Sci 26:278-290. https://doi.org/10.1111/jvs.12239

Closset-Kopp D, Chabrerie O, Valentin B et al (2007) When Oskar meets Alice: does a lack of trade-off in r/K-strategies make Prunus serotina a successful invader of European forests? For Ecol Manage 247:120-130. https://doi.org/10. 1016/j.foreco.2007.04.023

Core Team R (2017) R: a language and environment for statistical computing. R Foundation for Statistical Computing, Vienna

Davis MA (2003) Biotic globalization: does competition from introduced species threaten biodiversity? Bioscience 53:481-489. https://doi.org/10.1641/00063568(2003)053\%5b0481:BGDCFI\%5d2.0.CO;2

Davis MA, Thompson K, Grime PJ (2005) Invasibility: the local mechanism driving community assembly and species diversity. Ecography 28:696-704. https://doi.org/10.1111/ j.2005.0906-7590.04205.x

Dyderski MK, Jagodziński AM (2016) Patterns of plant invasions at small spatial scale correspond with that at the whole country scale. Urban Ecosyst. https://doi.org/10. 1007/s11252-015-0524-y

Dyderski MK, Jagodziński AM (2018) Drivers of invasive tree and shrub natural regeneration in temperate forests. Biol Invasions 20(9):2363-2379. https://doi.org/10.1007/ s10530-018-1706-3

Dyderski MK, Czapiewska N, Zajdler M et al (2016) Functional diversity, succession, and human-mediated disturbances in raised bog vegetation. Sci Total Environ 562:648-657. https://doi.org/10.1016/j.scitotenv.2016.04.102

Dyderski MK, Tyborski J, Jagodziński AM (2017) The utility of ancient forest indicator species in urban environments: a case study from Poznań, Poland. Urban For Urban Green 27:76-83. https://doi.org/10.1016/j.ufug.2017.06.016

Dzwonko Z (1993) Relations between the floristic composition of isolated young woods and their proximity to ancient woodland. J Veg Sci 4:693-698. https://doi.org/10.2307/ 3236135
Ellenberg H (1988) Vegetation ecology of central Europe. Cambridge University Press, Cambridge

Essl F, Hulme PE, Jeschke JM et al (2017) Scientific and normative foundations for the valuation of alien-species impacts: thirteen core principles. Bioscience 67:166-178. https://doi.org/10.1093/biosci/biw160

Fox JF (1979) Intermediate-disturbance hypothesis. Science 204:1344-1345. https://doi.org/10.1126/science.204.4399. 1344

Frelich LE, Reich PB, Peterson DW (2017) The Changing Role of Fire in Mediating the Relationships among Oaks, Grasslands, Mesic Temperate Forests and Boreal Forests in the Lake States. J Sustain For 36:421-432. https://doi.org/ 10.1080/10549811.2017.1296777

Gallien L, Saladin B, Boucher FC et al (2016) Does the legacy of historical biogeography shape current invasiveness in pines? New Phytol 209:1096-1105. https://doi.org/10. 1111/nph.13700

Gazda A, Szwagrzyk J (2016) Introduced species in Polish National Parks: distribution, abundance and management approaches. In: Krumm F, Vítková L (eds) Introduced tree species in European forests: opportunities and challenges. European Forest Institute, Freiburg, pp 168-175

Grime PJ (2001) Plant strategies, vegetation processes, and ecosystem properties, 2nd edn. Wiley, Chichester

Groves RH (2006) Are some weeds sleeping? Some concepts and reasons. Euphytica 148:111-120. https://doi.org/10. 1007/s10681-006-5945-5

Halarewicz A (2012) Właściwości ekologiczne i skutki rozprzestrzeniania się czeremchy amerykańskiej Padus serotina (Ehrh.) Borkh. w wybranych fitocenozach leśnych. Wydawnictwo Uniwersytetu Przyrodniczego, Wrocław

Herben T, Chytrý M, Klimešová J (2016) A quest for specieslevel indicator values for disturbance. J Veg Sci 27:628-636. https://doi.org/10.1111/jvs.12384

Herben T, Klimešová J, Chytrý M (2018) Philip Grime's fourth corner: are there plant species adapted to high disturbance and low productivity? Oikos. https://doi.org/10.1111/oik. 05090

Hermy M, Honnay O, Firbank L et al (1999) An ecological comparison between ancient and other forest plant species of Europe, and the implications for forest conservation. Biol Conserv 91:9-22. https://doi.org/10.1016/S00063207(99)00045-2

Hobbie SE, Reich PB, Oleksyn J et al (2006) Tree species effects on decomposition and forest floor dynamics in a common garden. Ecology 87:2288-2297. https://doi.org/10.1890/ 0012-9658(2006)87\%5b2288:TSEODA\%5d2.0.CO;2

Hobbs RJ, Huenneke LF (1992) Disturbance, diversity, and invasion: implications for conservation. Conserv Biol 6:324-337. https://doi.org/10.1046/j.1523-1739.1992. 06030324.x

Horodecki P, Jagodziński AM (2017) Tree species effects on litter decomposition in pure stands on afforested postmining sites. For Ecol Manag 406:1-11. https://doi.org/10. 1016/j.foreco.2017.09.059

Jagodziński AM, Dyderski MK, Rawlik M, Banaszczak P (2015) Plantation of coniferous trees modifies risk and size of Padus serotina (Ehrh.) Borkh. invasion-Evidence from 
a Rogów Arboretum case study. For Ecol Manage 357:84-94. https://doi.org/10.1016/j.foreco.2015.08.011

Jagodziński AM, Dyderski MK, Horodecki P, Rawlik K (2018) Limited dispersal prevents Quercus rubra invasion in a 14-species common garden experiment. Divers Distrib 24:403-414. https://doi.org/10.1111/ddi.12691

Jarošík V, Pyšek P, Kadlec T (2011) Alien plants in urban nature reserves: from red-list species to future invaders? NeoBiota 10:27-46. https://doi.org/10.3897/neobiota.10.1262

Jeschke JM (2014) General hypotheses in invasion ecology. Divers Distrib 20:1129-1134. https://doi.org/10.1111/ddi. 12258

Johnstone JF, Allen CD, Franklin JF et al (2016) Changing disturbance regimes, ecological memory, and forest resilience. Front Ecol Environ 14:369-378. https://doi.org/10. 1002/fee. 1311

Jonášová M, Prach K (2004) Central-European mountain spruce (Picea abies (L.) Karst.) forests: regeneration of tree species after a bark beetle outbreak. Ecol Eng 23:15-27. https://doi.org/10.1016/j.ecoleng.2004.06.010

Kleyer M, Bekker RM, Knevel IC et al (2008) The LEDA Traitbase: a database of life-history traits of the Northwest European flora. J Ecol 96:1266-1274. https://doi.org/10. 1111/j.1365-2745.2008.01430.x

Klotz S, Kühn I, Durka W (2002) BIOLFLOR-Eine Datenbank zu biologisch-ökologischen Merkmalen der Gefäßpflanzen in Deutschland. Schriftenreihe für Vegetationskunde, Bundesamt für Naturschutz

Knapp S, Kühn I, Stolle J, Klotz S (2010) Changes in the functional composition of a Central European urban flora over three centuries. Perspect Plant Ecol Evol Syst 12:235-244. https://doi.org/10.1016/j.ppees.2009.11.001

Knight KS, Oleksyn J, Jagodzinski AM et al (2008) Overstorey tree species regulate colonization by native and exotic plants: a source of positive relationships between understorey diversity and invasibility. Divers Distrib 14:666-675. https://doi.org/10.1111/j.1472-4642.2008. 00468.x

Kozlowski TT, Pallardy SG (1997) Physiology of woody plants, 2nd edn. Academic Press, San Diego

Křivánek M, Pyšek P, Jarošík V (2006) Planting history and propagule pressure as predictors of invasion by woody species in a temperate region. Conserv Biol 20:1487-1498. https://doi.org/10.1111/j.1523-1739.2006.00477.x

Kučerová A, Rektoris L, Štechová T, Bastl M (2008) Disturbances on a wooded raised bog-how windthrow, bark beetle and fire affect vegetation and soil water quality? Folia Geobot 43:49-67

Laliberté E, Legendre P, Shipley B (2014) FD: Measuring functional diversity (FD) from multiple traits, and other tools for functional ecology. URL: https://cran.r-project. org/web/packages/FD/

Lockwood JL, Cassey P, Blackburn T (2005) The role of propagule pressure in explaining species invasions. Trends Ecol Evol 20:223-228. https://doi.org/10.1016/j.tree.2005. 02.004

Lonsdale WM (1999) Global patterns of plant invasions and the concept of invasibility. Ecology 80:1522-1536. https://doi. org/10.1890/0012-9658(1999)080\%5b1522:GPOPIA\% 5d2.0.CO;2
Mack RN, Simberloff D, Mark Lonsdale W et al (2000) Biotic invasions: causes, epidemiology, global consequences, and control. Ecol Appl 10:689-710. https://doi.org/10.1890/ 1051-0761(2000)010\%5b0689:BICEGC\%5d2.0.CO;2

Mueller KE, Eissenstat DM, Hobbie SE et al (2012) Tree species effects on coupled cycles of carbon, nitrogen, and acidity in mineral soils at a common garden experiment. Biogeochemistry 111:601-614. https://doi.org/10.1007/s10533011-9695-7

Muys B, Maddelein D, Lust N (1992) Ecology, practice and policy of black cherry (Prunus serotina Ehrh.) management in Belgium. Silva Gandav 57:28-45

Myczko Ł, Dylewski Ł, Zduniak P et al (2014) Predation and dispersal of acorns by European Jay (Garrulus glandarius) differs between a native (Pedunculate Oak Quercus robur) and an introduced oak species (Northern Red Oak Quercus rubra) in Europe. For Ecol Manag 331:35-39. https://doi. org/10.1016/j.foreco.2014.07.027

Nowak G, Kara M, Bernat Z, Cykowiak Z (2000) Wybrane zagadnienia z planu ochrony ekosystemów leśnych Wielkopolskiego Parku Narodowego. Morena 7:85-129

Obidziński A, Mędrzycki P, Kołaczkowska E et al (2016) Do David and Goliath Play the Same Game? Explanation of the Abundance of Rare and Frequent Invasive Alien Plants in Urban Woodlands in Warsaw, Poland. PLOS ONE 11:e0168365. https://doi.org/10.1371/journal.pone. 0168365

Oksanen J, Blanchet FG, Kindt R, et al (2016) “vegan” 2.3.3.— Community Ecology Package. URL http://CRAN.Rproject.org/package=vegan

Pairon M, Jonard M, Jacquemart A-L (2006) Modeling seed dispersal of black cherry, an invasive forest tree: how microsatellites may help? Can J For Res 36:1385-1394. https://doi.org/10.1139/x06-018

Peterken GF (1974) A method for assessing woodland flora for conservation using indicator species. Biol Conserv 6:239-245. https://doi.org/10.1016/0006-3207(74)900019

Pierce S, Brusa G, Vagge I, Cerabolini BEL (2013) Allocating CSR plant functional types: the use of leaf economics and size traits to classify woody and herbaceous vascular plants. Funct Ecol 27:1002-1010. https://doi.org/10.1111/ 1365-2435.12095

Prach K, Pyšek P, Bastl M (2001) Spontaneous vegetation succession in human-disturbed habitats: a pattern across seres. Appl Veg Sci 4:83-88. https://doi.org/10.1111/j. 1654-109X.2001.tb00237.x

Prach K, Řehounková K, Lencová K et al (2014) Vegetation succession in restoration of disturbed sites in Central Europe: the direction of succession and species richness across 19 seres. Appl Veg Sci 17:193-200. https://doi.org/ 10.1111/avsc. 12064

Purcel A (2009) Obce gatunki drzew i krzewów w Wielkopolskim Parku Narodowym-ich występowanie i rola w biocenozach Parku. Morena 14:35-191

Pyšek P, Prach K (1993) Plant invasions and the role of riparian habitats: a comparison of four species alien to Central Europe. J Biogeogr 20:413-420. https://doi.org/10.2307/ 2845589

Pyšek P, Jarošík V, Pergl J et al (2014) Temperate trees and shrubs as global invaders: the relationship between 
invasiveness and native distribution depends on biological traits. Biol Invasions 16:577-589. https://doi.org/10.1007/ s10530-013-0600-2

Ratyńska H, Wojterska M, Brzeg A, Kołacz M (2010) Multimedialna encyklopedia zbiorowisk roślinnych Polski. NFOSiGW, UKW, IETI

Reich PB, Oleksyn J, Modrzynski J et al (2005) Linking litter calcium, earthworms and soil properties: a common garden test with 14 tree species. Ecol Lett 8:811-818. https://doi. org/10.1111/j.1461-0248.2005.00779.x

Rice SK, Westerman B, Federici R (2004) Impacts of the exotic, nitrogen-fixing black locust (Robinia pseudoacacia) on nitrogen-cycling in a pine-oak ecosystem. Plant Ecol 174:97-107. https://doi.org/10.1023/B:VEGE. $0000046049.21900 .5 \mathrm{a}$

Richardson DM, Pyšek P (2006) Plant invasions: merging the concepts of species invasiveness and community invasibility. Prog Phys Geogr 30:409-431. https://doi.org/10. 1191/0309133306pp490pr

Richardson DM, Holmes PM, Esler KJ et al (2007) Riparian vegetation: degradation, alien plant invasions, and restoration prospects. Divers Distrib 13:126-139. https:// doi.org/10.1111/j.1366-9516.2006.00314.x

Riepšas E, Straigyté L (2008) Invasiveness and Ecological Effects of Red Oak (Quercus rubra L.) in Lithuanian Forests. Balt For 14:122-130

Roberts DR, Bahn V, Ciuti S et al (2017) Cross-validation strategies for data with temporal, spatial, hierarchical, or phylogenetic structure. Ecography 40:913-929. https://doi. org/10.1111/ecog.02881

Rodríguez J, Lorenzo P, González L (2017) Different growth strategies to invade undisturbed plant communities by Acacia dealbata Link. For Ecol Manag 399:47-53. https:// doi.org/10.1016/j.foreco.2017.05.007

Sádlo J, Vítková M, Pergl J, Pyšek P (2017) Towards sitespecific management of invasive alien trees based on the assessment of their impacts: the case of Robinia pseudoacacia. NeoBiota 35:1-34. https://doi.org/10.3897/ neobiota.35.11909

Sebert-Cuvillier E, Paccaut F, Chabrerie O et al (2007) Local population dynamics of an invasive tree species with a complex life-history cycle: a stochastic matrix model. Ecol Model 201:127-143. https://doi.org/10.1016/j.ecolmodel. 2006.09.005

Sork VL (1984) Examination of seed dispersal and survival in red oak, Quercus rubra (Fagaceae), using metal-tagged acorns. Ecology 65:1020-1022. https://doi.org/10.2307/ 1938075

Starfinger U, Kowarik I, Rode M, Schepker H (2003) From desirable ornamental plant to pest to accepted addition to the flora? - the perception of an alien tree species through the centuries. Biol Invasions 5:323-335. https://doi.org/10. 1023/B:BINV.0000005573.14800.07
Stohlgren TJ, Jarnevich C, Chong GW et al (2006) Scale and plant invasions: a theory of biotic acceptance. Preslia 78:405-426

Tecco PA, Díaz S, Cabido M, Urcelay C (2010) Functional traits of alien plants across contrasting climatic and land-use regimes: do aliens join the locals or try harder than them? J Ecol 98:17-27. https://doi.org/10.1111/j.1365-2745. 2009.01592.x

Thomsen MS, Wernberg T, South PM, Schiel DR (2016) To include or not to include (the invader in community analyses)? That is the question. Biol Invasions 18:1515-1521. https://doi.org/10.1007/s10530-016-1102-9

Tilman D (1986) Resources, competition and the dynamics of plant communities. In: Crawley M (ed) Plant Ecology. Blackwell Scientific Publications, Oxford, pp 51-75

Turetsky MR, Louis VLS (2006) Disturbance in Boreal Peatlands. In: Wieder RK, Vitt DH (eds) Boreal peatland ecosystems. Springer, Berlin Heidelberg, pp 359-379

Vanhellemont M, Verheyen K, Keersmaeker L et al (2009) Does Prunus serotina act as an agressive invader in areas with a low propagule pressure? Biol Invasions 11:1451-1462. https://doi.org/10.1007/s10530-008-9353-8

Vítková M, Müllerová J, Sádlo J et al (2017) Black locust (Robinia pseudoacacia) beloved and despised: a story of an invasive tree in Central Europe. For Ecol Manag 384:287-302. https://doi.org/10.1016/j.foreco.2016.10. 057

Wagner V, Chytrý M, Jiménez-Alfaro B et al (2017) Alien plant invasions in European woodlands. Divers Distrib 23:969-981. https://doi.org/10.1111/ddi.12592

Wasserstein RL, Lazar NA (2016) The ASA's statement on p-values: context, process, and purpose. Am Stat 70:129-133. https://doi.org/10.1080/00031305.2016. 1154108

Westoby M (1998) A leaf-height-seed (LHS) plant ecology strategy scheme. Plant Soil 199:213-227. https://doi.org/ 10.1023/A: 1004327224729

Woziwoda B, Potocki M, Sagan J et al (2014) Commercial forestry as a vector of alien tree species-the case of Quercus rubra L. introduction in Poland. Balt For 20:131-141

Zeppenfeld T, Svoboda M, DeRose RJ et al (2015) Response of mountain Picea abies forests to stand-replacing bark beetle outbreaks: neighbourhood effects lead to self-replacement. J Appl Ecol 52:1402-1411. https://doi.org/10.1111/13652664.12504

Zerbe S, Wirth P (2006) Non-indigenous plant species and their ecological range in Central European pine (Pinus sylvestris L.) forests. Ann For Sci 63:189-203. https://doi.org/10. 1051/forest:2005111

Ziegenhagen B, Kausch W (1995) Productivity of young shaded oaks (Quercus robur L.) as corresponding to shoot morphology and leaf anatomy. For Ecol Manag 72:97-108. https://doi.org/10.1016/0378-1127(94)03482-C 